\title{
Microsatellite instability in inflamed and neoplastic epithelium in ulcerative colitis
}

\author{
T Ishitsuka, H Kashiwagi, F Konishi
}

\begin{abstract}
Background-Several genetic alterations have been documented in dysplasia and cancer developing in ulcerative colitis (UC). However, the microsatellite instability (MSI) status has rarely been described, especially in the inflamed epithelium of UC.
\end{abstract}

Aims-To study MSI status during neoplastic and inflammatory changes in UC. Methods-Seventy five surgically resected samples of colorectal mucosa, taken from 16 colectomy specimens of patients with UC were examined: five patients had a long duration with dysplasia or cancer (UC-LD with neoplasm), seven patients had a long duration without neoplastic changes (UC-LD without neoplasm), and four patients had a short duration without neoplastic changes (UC-SD). In addition to MSI status examined by six microsatellite markers, p53 expression was compared among the three groups.

Results-With regard to non-neoplastic inflamed epithelium, MSI in two or more loci $(M S I \geqslant 2)$ was seen more frequently in the UC-LD without neoplasm group than in the UC-SD group (six of $14 v$ one of 12; $p=0.060$ ), and significantly more often than in the UC-LD with neoplasm group ( $\operatorname{six}$ of $14 v$ two of $23 ; p=0.016$ ). In the UC-LD without neoplasm group, MSI $\geqslant 2$ was detected significantly more frequently in patients with severe inflammation than in those with mild inflammation (six of nine $v$ none of five; $p=0.028$ ). With regard to neoplastic epithelium in the UC-LD with neoplasm group, MSI in two or more loci was found in three of 17 , and p53 overexpression was seen in 11 of 17 of the neoplastic lesions.

Conclusions-A high incidence of MSI in long standing UC with severe inflammation probably reflects genomic instability caused by repeated inflammatory stress. Thus, the influence of inflammation should be considered when estimating MSI in UC. It is possible that changes in p53 expression are important in the development of cancer in UC.

(f Clin Pathol 2001;54:526-532)

Keywords: microsatellite instability; p53; ulcerative colitis

Microsatellites are simple repetitive sequences of DNA that are scattered throughout the genome. These sequences are stably inherited, vary from individual to individual, and have a low alteration rate. ${ }^{12}$ Instability within these sequences has been recognised as a marker for genome wide mutations and DNA repair deficiencies. Microsatellite instability (MSI) has been detected in cancers associated with hereditary non-polyposis colorectal cancer syndrome (HNPCC), as well as in a variety of sporadic cancers, ${ }^{3-5}$ including colorectal cancers associated with ulcerative colitis (UC) ${ }^{6-8}$ MSI is a genetic condition not simply limited to malignant and premalignant tissue. Recently, there have been some reports detecting MSI in the non-neoplastic setting, including the inflammatory mucosa of UC. ${ }^{78}$

UC is an inflammatory bowel disease characterised by recurrent, often persistent inflammation of the colon. Patients with long standing UC have an increased risk for the development of colorectal carcinoma. ${ }^{9}$ Dysplasia is associated with, and often precedes, the development of invasive carcinomas in patients with UC. When dysplasia develops in UC, it is often widespread and multifocal, suggesting that neoplastic progression in this condition may result from abnormalities occurring over large regions of the colonic mucosa. ${ }^{10}$ Continuing inflammation and resultant DNA damage in the setting of UC can cause the accumulation of genetic alterations including MSI. Thus, in UC inflammatory mucosa with MSI may be a precursor of neoplastic changes. However, it is possible that normal DNA repair mechanisms become saturated as a result of the greatly increased cell turnover and proliferation that occurs in inflammatory bowel disease. ${ }^{7}$

To investigate the importance of MSI in neoplastic epithelium in UC, we examined MSI in inflamed and neoplastic epithelium in UC, and estimated the changes in MSI under the influence of inflammation. In addition, we examined p53 gene product overexpression.

\section{Methods}

SAMPLES

All materials were obtained from 16 patients with UC, who underwent surgery from 1976 to 1997 at our institute: five patients had a long duration with dysplasia or cancer (UC-LD with neoplasm group), seven patients had a long duration without neoplastic changes (UC-LD without neoplasm group), and four patients had a short duration without neoplastic changes (UC-SD group). Long duration was defined as five years or more, and short duration as four years or less. UC-LD with neoplasm cases were entirely long standing (more than 10 years). The characteristics of the patients and the indications for surgery are summarised in tables 1 and 2. In the UC-LD with neoplasm group, all cases underwent surgery for carcinoma or dysplasia associated with 
Table 1 Clinical characteristics of patients with neoplastic lesions (ulcerative colitis of long duration with neoplasm)

\begin{tabular}{|c|c|c|c|c|c|c|c|c|}
\hline \multicolumn{3}{|c|}{ Patient } & \multirow{2}{*}{$\begin{array}{l}\text { Duration } \\
\text { (years) }\end{array}$} & \multirow[b]{2}{*}{ Indication for operation } & \multicolumn{4}{|c|}{ Tumour } \\
\hline No. & Age & Sex & & & No. & Site & Class & Macroscopic type \\
\hline 1 & 75 & $\mathrm{~F}$ & 33 & Carcinoma & 1 & $\mathrm{R}$ & $\begin{array}{l}\text { Ca } \\
\text { HGD } \\
\text { LGD } \\
\text { IFD-P } \\
\text { HGD } \\
\text { LGD }\end{array}$ & $\begin{array}{l}\text { Ulcerated } \\
\text { Nodular } \\
\text { Villous } \\
\text { Villous } \\
\text { Granular } \\
\text { Granular }\end{array}$ \\
\hline 2 & 35 & M & 17 & Carcinoma & $\begin{array}{l}1 \\
2\end{array}$ & $\begin{array}{l}\mathrm{R} \\
\mathrm{T}\end{array}$ & $\begin{array}{l}\text { Ca } \\
\text { HGD } \\
\text { LGD } \\
\text { IFD-P }\end{array}$ & $\begin{array}{l}\text { Ulcerated } \\
\text { Flat } \\
\text { Flat } \\
\text { Flat }\end{array}$ \\
\hline 3 & 36 & $M$ & 16 & Stenosis of T/C (dysplasia on biopsy) & $\begin{array}{l}2 \\
3 \\
4\end{array}$ & $\begin{array}{l}\text { A } \\
\text { D } \\
\text { A }\end{array}$ & $\begin{array}{l}\mathrm{Ca} \\
\text { HGD } \\
\text { LGD } \\
\text { IFD-P } \\
\text { HGD } \\
\text { IFD-P } \\
\text { LGD } \\
\text { IFD-P }\end{array}$ & $\begin{array}{l}\text { Ulcerated } \\
\text { Villous } \\
\text { Villous } \\
\text { Flat } \\
\text { Flat } \\
\text { Flat } \\
\text { Flat } \\
\text { Flat }\end{array}$ \\
\hline 4 & 37 & $\mathrm{~F}$ & 12 & $\begin{array}{l}\text { Dysplasia of rectum and rectovaginal } \\
\text { fistula }\end{array}$ & 1 & $\mathrm{~T}$ & $\begin{array}{l}\mathrm{Ca} \\
\mathrm{HGD} \\
\text { IFD-N }\end{array}$ & $\begin{array}{l}\text { Ulcerated } \\
\text { Nodular } \\
\text { Villous }\end{array}$ \\
\hline 5 & 55 & $\mathrm{~F}$ & 15 & Dysplasia of rectum & 1 & $\mathrm{R}$ & $\begin{array}{l}\text { HGD } \\
\text { LGD } \\
\text { IFD-P } \\
\text { IFD-P } \\
\text { IFD-N }\end{array}$ & $\begin{array}{l}\text { Flat } \\
\text { Flat } \\
\text { Flat } \\
\text { Flat } \\
\text { Flat }\end{array}$ \\
\hline
\end{tabular}

Tumour site: $\mathrm{A}$, ascending colon; $\mathrm{D}$, descending colon; $\mathrm{R}$, rectum; $\mathrm{T}$, transverse colon.

Tumour class: Ca, carcinoma; HGD, high grade dysplasia; IFD-N, indefinite for dysplasia, probably negative; IFD-P, indefinite for dysplasia, probably positive; LGD, low grade dysplasia.

UC; however, in the UC-LD without neoplasm or SD group the indication for surgery was severe inflammation.

\section{HISTOLOGICAL EVALUATION}

Routine haematoxylin and eosin stained slides from resected specimens were retrieved from surgical pathology files and reviewed by two observers. All lesions were classified according to the criteria defined by Riddell. ${ }^{11}$

Based on the initial histological review, multiple paraffin wax blocks were selected from each case, containing areas with both nonneoplastic and neoplastic lesions. However, neoplastic tumours associated with UC tended to include multiple stages of carcinogenesis within a tumour. Therefore, we chose different representative lesions for examination (table 1). A total of 75 colonic tissue samples from 16 patients with UC were examined. Of these specimens, there were 49 lesions negative for dysplasia (NFD), nine lesions indefinite for dysplasia (IFD), six lesions of low grade

Table 2 Clinical characteristics of patients without neoplasms (UC-SD and UC-LD without neoplasm)

\begin{tabular}{llllll}
\hline Group & $\begin{array}{l}\text { Patient } \\
\text { no. }\end{array}$ & $\begin{array}{l}\text { Age } \\
\text { (years) }\end{array}$ & Sex & $\begin{array}{l}\text { Duration of } \\
\text { disease (years) }\end{array}$ & $\begin{array}{l}\text { Indication for } \\
\text { surgery }\end{array}$ \\
\hline UC-SD & 1 & 37 & $\mathrm{M}$ & 0.5 & Steroid resistant \\
& 2 & 54 & $\mathrm{M}$ & 0.5 & Steroid resistant \\
& 3 & 22 & $\mathrm{~F}$ & 2 & Perforation \\
& 4 & 39 & $\mathrm{~F}$ & 2 & Toxic megacolon \\
UC-LD without neoplasm & 1 & 24 & $\mathrm{~F}$ & 5 & Steroid resistant \\
& 2 & 25 & $\mathrm{M}$ & 6 & Steroid resistant \\
& 3 & 44 & $\mathrm{~F}$ & 7 & Steroid resistant \\
& 4 & 26 & $\mathrm{~F}$ & 8 & Steroid resistant \\
& 5 & 28 & $\mathrm{~F}$ & 8 & Steroid dependent \\
6 & 25 & $\mathrm{~F}$ & 12 & Steroid resistant \\
& 7 & 27 & $\mathrm{~F}$ & 13 & Steroid resistant \\
\hline
\end{tabular}

UC-LD, ulcerative colitis of long duration; UC-SD, ulcerative colitis of short duration. dysplasia (LGD), seven lesions of high grade dysplasia (HGD), and four lesions with invasive carcinoma $(\mathrm{Ca})$.

Furthermore, the inflammatory specimens were graded by Matts's classification ${ }^{12}$ as follows: normal appearance (1); some infiltration of the mucosa or lamina propria with either round cells or polymorphs (2); much cellular infiltration of the mucosa, lamina propria, and submucosa (3); presence of crypt abscesses, with much infiltration of all layers of the mucosa (4); ulceration, erosion, or necrosis of the mucosa, with cellular infiltration of some or all of its layers (5). Inflammation was regarded as severe when a Matts's score of 3 or more was found.

The selected paraffin wax blocks from all lesions were serially sectioned and numbered consecutively; $5 \mu \mathrm{m}$ thick sections were cut and applied to glass slides.

\section{MICROSATELLITE INSTABILITY}

DNA was extracted from tissue sections embedded in paraffin wax as described previously. Specific histological areas, measuring approximately $1 \mathrm{~mm}$ or less, were removed under a dissecting microscope using a needle. When we sampled the inflamed mucosa, we tried to sample the epithelium only and did not take lymphoid follicles. Because the entire mucosa was considered to be influenced by repeated inflammation, we used tissue from matched corresponding smooth muscle tissue of the colon as a normal control.

The procured cells were dewaxed in xylene and digested overnight at $55^{\circ} \mathrm{C}$ with $100 \mu \mathrm{l}$ of a digestion buffer containing proteinase K (Ambion Inc, Austin, Texas, USA). 


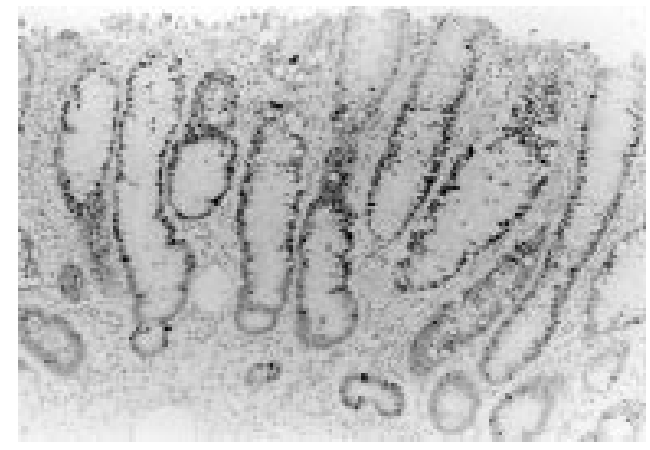

Figure 1 Immunohistochemical expression of p53 in low grade dysplasia (tumour number 2 in patient number 1 of the ulcerative colitis of long duration with neoplasm group). Diffuse aggregation of positive cells categorised as (++) was seen.

DNA was amplified by the polymerase chain reaction (PCR) as described previously. Six microsatellite markers (D2S123, D3S1611, D3S1029, TP53, Mfd26, and BAT26) were used to determine the MSI status. In addition, the gene encoding transforming growth factor $\beta$ receptor type II (TGF- $\beta$ RII (poly A)), which has been recognised as a target gene of a genetic instability carcinogenic pathway, ${ }^{13}$ was examined in the UC with neoplasm group. The reaction mixture $(25 \mu \mathrm{l})$ contained $1.0 \mu \mathrm{l}$ of genomic DNA, $0.20 \mu \mathrm{M}$ each of an unlabelled primer and a primer labelled with digoxygenin, $25 \mu \mathrm{M}$ of deoxynucleotide triphosphate, 10× PCR buffer, and 0.25 units of recombinant Taq DNA polymerase (TaKaRa Biomedicals, Shiga, Japan). PCR products $(4 \mu \mathrm{l})$ were mixed with $3 \mu \mathrm{l}$ of the sequencing stop solution (Amersham, Little Chalfont, UK) and denatured at $90^{\circ} \mathrm{C}$ for five minutes. Next, $5 \mu$ aliquots of the denatured materials were electrophoresed on an $8 \%$ polyacrylamide gel containing $7 \mathrm{M}$ urea for three hours at $1500 \mathrm{~V}$. After electrophoresis, the DNA samples were transferred to a Hybond-N membrane (Amersham) and the membrane was

Table 3 Microsatellite instability (MSI), Matts's classification, and p53 overexpression in ulcerative colitis of long duration with neoplasm (neoplastic and inflamed epithelium)

\begin{tabular}{|c|c|c|c|c|c|c|c|c|c|c|c|c|}
\hline $\begin{array}{l}\text { Patient } \\
\text { no. }\end{array}$ & $\begin{array}{l}\text { Region } \\
\text { no. }\end{array}$ & Class & $A$ & $B$ & $C$ & $D$ & $E$ & $F$ & $\begin{array}{l}\text { Total } \\
\text { MSI }\end{array}$ & $G$ & $\begin{array}{l}\text { Matts's } \\
\text { score }\end{array}$ & $\begin{array}{l}\text { p53 over } \\
\text { expression }\end{array}$ \\
\hline 1 & 1 & $\begin{array}{l}\text { Ca } \\
\text { HGD } \\
\text { LGD } \\
\text { IFD-P } \\
\mathrm{N} \\
\mathrm{N} \\
\mathrm{HGD} \\
\text { LGD } \\
\mathrm{N} \\
\mathrm{N} \\
\mathrm{N} \\
\mathrm{N} \\
\mathrm{N}\end{array}$ & $\begin{array}{l}\star \\
t \\
t \\
t \\
\star \\
+ \\
t \\
t\end{array}$ & $\begin{array}{l}t \\
t \\
t \\
t \\
t \\
t \\
t \\
t \\
t \\
t \\
t \\
t \\
t\end{array}$ & $\begin{array}{l}\star \\
\dagger \\
\dagger \\
t \\
t \\
t \\
\star \\
\dagger \\
t\end{array}$ & $\begin{array}{l}\dagger \\
\dagger \\
\dagger \\
\dagger \\
\star \\
\dagger \\
\dagger \\
+ \\
+ \\
\dagger \\
\dagger \\
\star\end{array}$ & $\begin{array}{l}t \\
t \\
t \\
t \\
t \\
t \\
t \\
t \\
t \\
t \\
t \\
t \\
t\end{array}$ & $\begin{array}{l}t \\
\star \\
t \\
t \\
+ \\
t \\
t \\
+ \\
t \\
t \\
+ \\
t \\
t\end{array}$ & $\begin{array}{l}2 \\
1 \\
0 \\
0 \\
1 \\
1 \\
0 \\
1 \\
0 \\
1 \\
0 \\
1 \\
0\end{array}$ & $\begin{array}{l}t \\
t \\
+ \\
+ \\
+ \\
+ \\
+ \\
+ \\
+ \\
+ \\
+ \\
+ \\
+\end{array}$ & $\begin{array}{l}1 \\
2 \\
\\
3 \\
1 \\
1 \\
1 \\
1\end{array}$ & $\begin{array}{l}(-) \\
(-) \\
(-) \\
(-) \\
(-) \\
(-) \\
(++) \\
(++) \\
(-) \\
(-) \\
(-) \\
(-) \\
(-)\end{array}$ \\
\hline 2 & $\begin{array}{l}1 \\
2\end{array}$ & $\begin{array}{l}\mathrm{Ca} \\
\mathrm{N} \\
\mathrm{HGD} \\
\text { LGD } \\
\text { IFD-P } \\
\mathrm{N} \\
\mathrm{N} \\
\mathrm{N}\end{array}$ & $\begin{array}{l}\star \\
t \\
t \\
t \\
\dagger \\
\star \\
\star\end{array}$ & $\begin{array}{l}t \\
t \\
t \\
t \\
t \\
t \\
t \\
t\end{array}$ & $\begin{array}{l}t \\
t \\
t \\
\star \\
t \\
t \\
t\end{array}$ & $\begin{array}{l}\dagger \\
\star \\
\star \\
\star\end{array}$ & $\begin{array}{l}\star \\
\dagger \\
\dagger \\
\star \\
\dagger \\
\star \\
+ \\
+\end{array}$ & $\begin{array}{l}t \\
t \\
t \\
+ \\
t \\
+ \\
t\end{array}$ & $\begin{array}{l}3 \\
0 \\
0 \\
2 \\
0 \\
3 \\
1 \\
2\end{array}$ & $\begin{array}{l}t \\
+ \\
+ \\
+ \\
+ \\
+ \\
+ \\
+\end{array}$ & $\begin{array}{l}1 \\
1 \\
3\end{array}$ & $\begin{array}{l}(++) \\
(-) \\
(+) \\
(+) \\
(-) \\
(-) \\
(-) \\
(-)\end{array}$ \\
\hline 3 & $\begin{array}{l}3 \\
4\end{array}$ & $\begin{array}{l}\mathrm{Ca} \\
\text { HGD } \\
\text { LGD } \\
\text { IFD-P } \\
\mathrm{N} \\
\text { HGD } \\
\text { IFD-P } \\
\text { LGD } \\
\text { IFD-P } \\
\mathrm{N} \\
\mathrm{N} \\
\mathrm{N}\end{array}$ & $\begin{array}{l}\dagger \\
\dagger \\
\dagger \\
\dagger\end{array}$ & $\begin{array}{l}t \\
t \\
t \\
t \\
t \\
t \\
t \\
t \\
t \\
t \\
t \\
t\end{array}$ & $\begin{array}{l}\dagger \\
t \\
\dagger \\
\star \\
\dagger\end{array}$ & $\begin{array}{l}t \\
t \\
t \\
t \\
t \\
t \\
\star \\
+ \\
t \\
t \\
+ \\
t\end{array}$ & $\begin{array}{l}t \\
t \\
t \\
t \\
t \\
t \\
t \\
t \\
t \\
t \\
t \\
t\end{array}$ & $\begin{array}{l}+ \\
t \\
\star \\
+ \\
+ \\
+ \\
+ \\
+ \\
+ \\
\star \\
+ \\
+\end{array}$ & $\begin{array}{l}0 \\
0 \\
1 \\
0 \\
1 \\
0 \\
1 \\
0 \\
0 \\
1 \\
1 \\
1\end{array}$ & $\begin{array}{l}+ \\
t \\
+ \\
+ \\
+ \\
+ \\
+ \\
+ \\
+ \\
+ \\
+ \\
+\end{array}$ & $\begin{array}{l}1 \\
1 \\
2\end{array}$ & $\begin{array}{l}(++) \\
(++) \\
(++) \\
(++) \\
(-) \\
(-) \\
(-) \\
(-) \\
(-) \\
(-) \\
(-) \\
(-)\end{array}$ \\
\hline 4 & 1 & $\begin{array}{l}\mathrm{Ca} \\
\mathrm{HGD} \\
\text { IFD-N } \\
\mathrm{N} \\
\mathrm{N} \\
\mathrm{N} \\
\mathrm{N} \\
\mathrm{N}\end{array}$ & $\stackrel{\star}{\star}$ & $\begin{array}{l}t \\
t \\
t \\
t \\
t \\
t \\
t \\
t\end{array}$ & $\begin{array}{l}t \\
t \\
t \\
t \\
t \\
t \\
t \\
t\end{array}$ & $\begin{array}{l}t \\
t \\
+ \\
+ \\
t \\
t \\
t \\
t\end{array}$ & $\begin{array}{l}t \\
\star \\
t \\
t \\
t \\
t \\
t\end{array}$ & $\begin{array}{l}t \\
t \\
+ \\
t \\
+ \\
t \\
+ \\
t\end{array}$ & $\begin{array}{l}0 \\
0 \\
1 \\
0 \\
0 \\
0 \\
1 \\
1\end{array}$ & $\begin{array}{l}\dagger \\
t \\
+ \\
+ \\
+ \\
+ \\
+ \\
+\end{array}$ & $\begin{array}{l}3 \\
2 \\
2 \\
2 \\
3\end{array}$ & $\begin{array}{l}(++) \\
(++) \\
(-) \\
(-) \\
(-) \\
(-) \\
(-) \\
(-)\end{array}$ \\
\hline 5 & 1 & $\begin{array}{l}\text { HGD } \\
\text { LGD } \\
\text { IFD-P } \\
\text { IFD-P } \\
\text { IFD-N } \\
\mathrm{N} \\
\mathrm{N} \\
\mathrm{N}\end{array}$ & $\begin{array}{l}t \\
t \\
t \\
t \\
t \\
t \\
t \\
t\end{array}$ & $\begin{array}{l}t \\
\star \\
t \\
t \\
t \\
t \\
t \\
t\end{array}$ & $\begin{array}{l}t \\
t \\
t \\
t \\
t \\
t \\
t \\
t\end{array}$ & $\begin{array}{l}t \\
t \\
t \\
t \\
t \\
t \\
t \\
t\end{array}$ & $\begin{array}{l}t \\
t \\
t \\
t \\
t \\
t \\
t \\
t\end{array}$ & $\begin{array}{l}t \\
t \\
t \\
t \\
+ \\
+ \\
+ \\
t\end{array}$ & $\begin{array}{l}0 \\
1 \\
0 \\
0 \\
0 \\
0 \\
0 \\
0\end{array}$ & $\begin{array}{l}t \\
t \\
t \\
t \\
t \\
t \\
t \\
t\end{array}$ & $\begin{array}{l}1 \\
2 \\
1\end{array}$ & $\begin{array}{l}(-) \\
(++) \\
(-) \\
(++) \\
(-) \\
(-) \\
(-) \\
(-)\end{array}$ \\
\hline
\end{tabular}

Microsatellite markers: A, D2S123; B, D2S1611; C, BAT26; D, Mfd26; E, TP53; F, D3S1629; G, TGFßRII (poly A). MSI is indicated by an asterisk.

$\mathrm{Ca}$, carcinoma; HGD, high grade dysplasia; IFD-N, indefinite for dysplasia, probably negative; IFD-P, indefinite for dysplasia, probably positive; LGD, low grade dysplasia. 
Table 4 Microsatellite instability (MSI), Matts's classification and p53 overexpression in UC-LD without neoplasm and UC-SD (inflamed epithelium)

\begin{tabular}{|c|c|c|c|c|c|c|c|c|c|c|c|c|}
\hline Group & $\begin{array}{l}\text { Patient } \\
\text { no. }\end{array}$ & $\begin{array}{l}\text { Region } \\
\text { no. }\end{array}$ & Class & $A$ & $B$ & $C$ & $D$ & $E$ & $F$ & $\begin{array}{l}\text { Total } \\
\text { MSI }\end{array}$ & $\begin{array}{l}\text { Matts's } \\
\text { score }\end{array}$ & $\begin{array}{l}\text { p53 } \\
\text { over-expression }\end{array}$ \\
\hline \multirow[t]{12}{*}{ UC-SD } & \multirow[t]{3}{*}{1} & 1 & $\mathrm{~N}$ & $\star$ & $\dagger$ & + & $\dagger$ & + & + & 1 & 4 & $(-)$ \\
\hline & & 2 & $\mathrm{~N}$ & $t$ & $t$ & $\star$ & $t$ & $t$ & $\star$ & 2 & 3 & $(-)$ \\
\hline & & 3 & $\mathrm{~N}$ & $t$ & $t$ & $t$ & $t$ & $t$ & $\star$ & 1 & 4 & $(-)$ \\
\hline & \multirow[t]{3}{*}{2} & 1 & $\mathrm{~N}$ & $\dagger$ & $\dagger$ & $t$ & $\dagger$ & $\dagger$ & $\star$ & 1 & 4 & $(-)$ \\
\hline & & 2 & $\mathrm{~N}$ & $t$ & $t$ & $t$ & $\star$ & $t$ & $t$ & 1 & 3 & $(-)$ \\
\hline & & 3 & $\mathrm{~N}$ & $t$ & $t$ & $t$ & $\dagger$ & $t$ & $\star$ & 1 & 4 & $(-)$ \\
\hline & \multirow[t]{3}{*}{3} & 1 & $\mathrm{~N}$ & & $t$ & $t$ & $t$ & $t$ & + & 0 & 2 & $(-)$ \\
\hline & & 2 & $\mathrm{~N}$ & & $t$ & $\dagger$ & $t$ & $t$ & $t$ & 0 & 3 & $(-)$ \\
\hline & & 3 & $\mathrm{~N}$ & $\dagger$ & $\dagger$ & $\dagger$ & $\dagger$ & & $\star$ & 1 & 2 & $(-)$ \\
\hline & \multirow[t]{3}{*}{4} & 1 & $\mathrm{~N}$ & $t$ & $t$ & $t$ & $t$ & $t$ & $t$ & 0 & 1 & $(-)$ \\
\hline & & 2 & $\mathrm{~N}$ & $t$ & $t$ & $\dagger$ & $\dagger$ & $t$ & $t$ & 0 & 3 & $(-)$ \\
\hline & & 3 & $\mathrm{~N}$ & $t$ & $t$ & $t$ & & $t$ & $\star$ & 1 & 4 & $(-)$ \\
\hline \multirow[t]{14}{*}{ UC-LD without neoplasm } & \multirow[t]{2}{*}{1} & $\mathrm{~L}$ & $\mathrm{~N}$ & & & t & $\dagger$ & + & $t$ & 0 & 2 & $(-)$ \\
\hline & & $\mathrm{R}$ & $\mathrm{N}$ & & $t$ & $t$ & $t$ & $\star$ & $t$ & 1 & 4 & $(-)$ \\
\hline & \multirow[t]{2}{*}{2} & $\mathrm{~L}$ & $\mathrm{~N}$ & & $\dagger$ & & $\star$ & $\star$ & $\dagger$ & 2 & 4 & $(-)$ \\
\hline & & $\bar{R}$ & $\mathrm{~N}$ & & $t$ & $t$ & $\star$ & $\star$ & $t$ & 2 & 3 & $(-)$ \\
\hline & \multirow[t]{2}{*}{3} & $\mathrm{~L}$ & $\mathrm{~N}$ & & & & $\dagger$ & & $t$ & 0 & 1 & $(-)$ \\
\hline & & $\mathrm{L}$ & $\mathrm{N}$ & + & & & $t$ & & $t$ & 0 & 2 & $(-)$ \\
\hline & \multirow[t]{2}{*}{4} & $\mathrm{~L}$ & $\mathrm{~N}$ & & $\star$ & $t$ & $t$ & $t$ & $t$ & 1 & 3 & $(-)$ \\
\hline & & $\mathrm{R}$ & $\mathrm{N}$ & + & $\star$ & $t$ & $t$ & $\star$ & $t$ & 2 & 3 & $(-)$ \\
\hline & \multirow[t]{2}{*}{5} & $\mathrm{~L}$ & $\mathrm{~N}$ & $\star$ & & & $\star$ & $t$ & $t$ & 2 & 3 & $(-)$ \\
\hline & & $\mathrm{R}$ & $\mathrm{N}$ & & & & $\star$ & $\star$ & $t$ & 2 & 3 & $(-)$ \\
\hline & \multirow[t]{2}{*}{6} & $\mathrm{~L}$ & $\mathrm{~N}$ & $t$ & $t$ & $t$ & $\star$ & $t$ & $t$ & 1 & 3 & $(-)$ \\
\hline & & $\mathrm{R}$ & $\mathrm{N}$ & $\dagger$ & $t$ & $\star$ & $\star$ & $\dagger$ & $t$ & 2 & 3 & $(-)$ \\
\hline & \multirow[t]{2}{*}{7} & $\mathrm{~L}$ & $\mathrm{~N}$ & $t$ & $t$ & $t$ & $t$ & $t$ & $t$ & 0 & 2 & $(-)$ \\
\hline & & $\mathrm{L}$ & $\mathrm{N}$ & $\star$ & $t$ & $t$ & $t$ & $t$ & $t$ & 1 & 2 & $(-)$ \\
\hline
\end{tabular}

Microsatellite markers: A, D2S123; B, D2S1611; C, BAT26; D, Mfd26; E, TP53; F, D3S1629; G, TGFßRII (poly A).

MSI is indicated by an asterisk.

UC-LD, ulcerative colitis of long duration; UC-SD, ulcerative colitis of short duration

washed with antidigoxigenin antibody conjugated with alkaline phosphatase, as reported previously. After the addition of Lumi-phos530 (Wako, Osaka, Japan), the nylon membrane was exposed to $x$ ray film for three to 12 hours.

Allelic shift (instability) of a microsatellite was defined by the presence of at least one band in the DNA from the lesion that was not present in the control smooth muscle tissue.

IMMUNOHISTOCHEMISTORY FOR THE p53 GENE PRODUCT

p53 status was examined immunohistochemically with a mouse monoclonal antibody, DO7 (DAKO, Nutley, New Jersey, USA), specific to the human p53 wild-type and mutant proteins at a dilution of $1 / 100$, using the method reported previously. Immunostaining was performed using the streptavidin-biotin immunoperoxidase (SAB) method in dewaxed sections after antigen retrieval with a heat induced epitope retrieval method. Positive p53 nuclear staining was categorised into the following three patterns: not stained or only a few scattered positively stained cells $(-)$; localised aggregation of positive cells $(+)$, or diffuse aggregation of positive cells $(++)$ (fig 1 ).

\section{STATISTICAL ANALYSIS}

We used contingency table analysis, and calculated Fisher's exact probability; $p$ values less than 0.05 were considered significant.

\section{Results}

Seventy five tissue samples were examined for MSI. Forty samples were positive for MSI. Among the six microsatellites examined, 28 samples had MSI in one locus, 10 samples in two loci, and two samples in three loci (tables 3 and $4^{4}$ ). When MSI was found in at least one locus, it was defined as $M S I \geqslant 1$, and $M S I \geqslant 2$ was defined as MSI in two or more loci. Figure
2 shows a representative gel demonstrating MSI using the D2S123 (fig 1A) and p53 (fig 1B) microsatellite markers.

With regard to the 49 non-neoplastic lesions, $M S I \geqslant 1$ and $M S I \geqslant 2$ were found in 31 and nine lesions, respectively (table 5). Although, $M S I \geqslant 1$ was found with similar frequency among the three groups, MSI $\geqslant 2$ tended to be found more frequently in UC-LD without neoplasm than in UC-SD (six of $14 v$ one of $12 ; \mathrm{p}=0.060$ ), and significantly more frequently than in UC-LD with neoplasm (six of $14 v$ two of $23 ; \mathrm{p}=0.016)$. In addition, in UC-LD without neoplasm, MSI $\geqslant 2$ was detected significantly more frequently in patients with severe inflammation (Matts's score 3 or 4 ) than in patients with mild inflammation (Matts's score 1 or 2) (six of nine $v$ none of five; $\mathrm{p}=0.028$ ). In severe inflammation, $M S I \geqslant 2$ was significantly more frequent in UC-LD without neoplasm than in UC-SD (six of nine $v$ one of nine; $\mathrm{p}=0.025$ ).

With regard to the UC-LD with neoplasm group, MSI was detected both in nonneoplastic and in neoplastic lesions (not significant). Among the four invasive cancers, two lesions had MSI $\geqslant 2$ (1.1 and 2.1; table 6). MSI in TGF- $\beta$ RII (poly A repeat) was not found in these invasive cancers, or in the other neoplastic lesions. p53 overexpression was detected in $65 \%$ of neoplastic lesions, and was not seen in non-neoplastic lesions (11 of $17 v$ zero of $23 ; p=0.000006)$. In addition, in the neoplastic lesions, severe MSI was seen in two of the 11 p53 positive lesions and in one of the six p53 negative lesions.

\section{Discussion}

MSI has been described in non-neoplastic lesions such as pancreatitis, ${ }^{14}$ intestinal metaplasia, ${ }^{15} 16$ and reactive lymphoid infiltrates ${ }^{17}$ of the stomach, and Barrett's metaplasia of the 
A

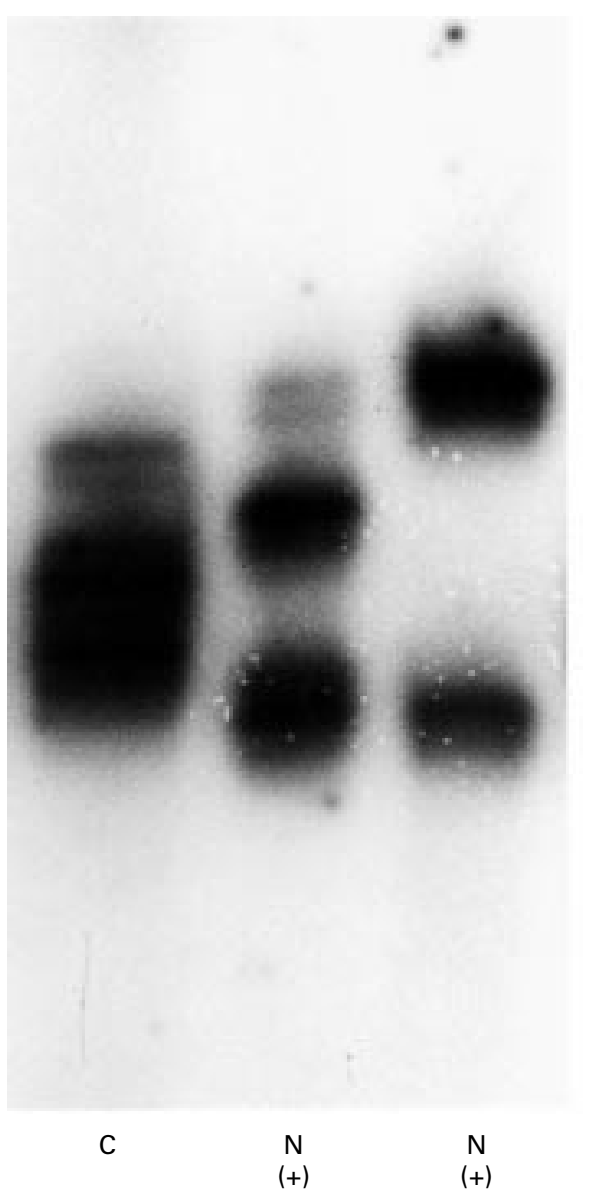

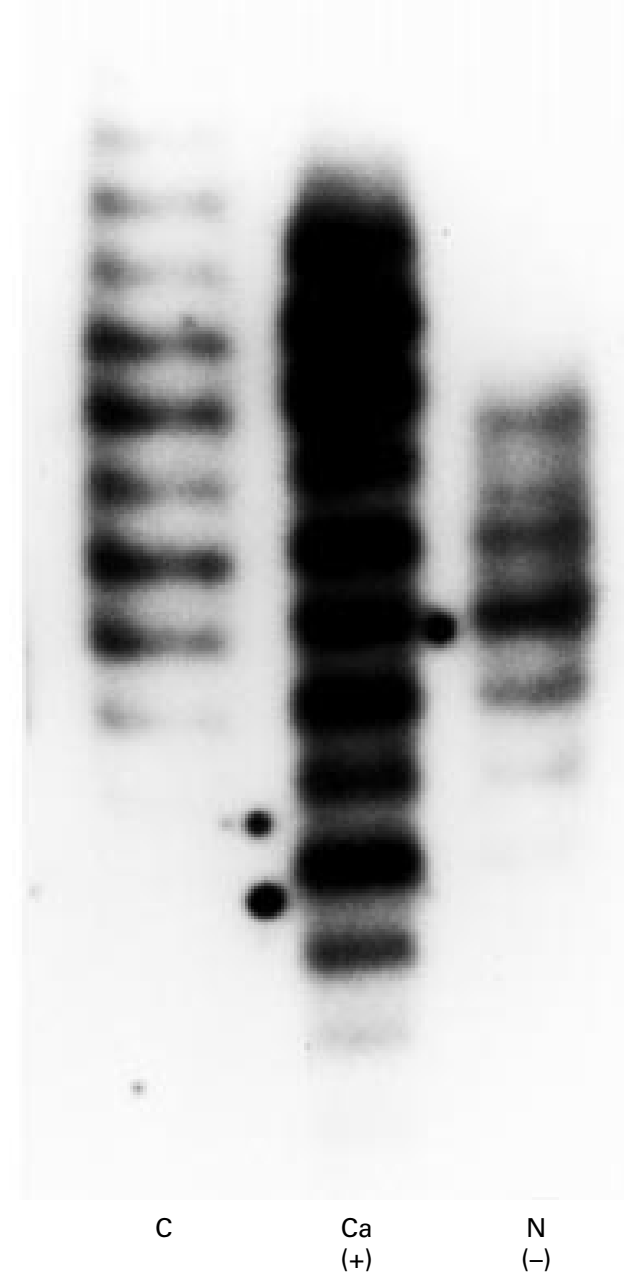

$(+)$

Figure 2 Microsatellite instability (MSI) in ulcerative colitis (UC) DNA. (A) MSI of D2S123 in non-neoplastic mucosal DNA. These two lesions existed in separate mucosa. (B) MSI of p53 was detected in DNA from the carcinoma, but not in non-neoplastic mucosal DNA. C, constitutional DNA as a control (from smooth muscle tissue); $N$, non-neoplastic mucosal DNA; Ca, DNA from carcinoma; (+), positive for MSI; (-), negative for MSI.

oesophagus. ${ }^{18}$ These lesions are almost always associated with inflammatory diseases, and in these situations it has been suggested that chronic inflammation causes genetic alteration and carcinogenesis. With regard to UC, the first report of MSI in a UC associated neoplasm was by Suzuki et al. ${ }^{6}$ They detected MSI in at least one of five loci in $19 \%$ of dysplasia and $21 \%$ of cancer cases. Furthermore, there have been some reports of MSI in non-neoplastic mucosa affected by UC. First, Brentnall et al found MSI in at least one locus among an average of seven loci in $60 \%$ of nonneoplastic mucosa, in $85 \%$ of high grade dysplasias, and in $40 \%$ of carcinomas, and in two or more loci in $50 \%, 46 \%$, and $40 \%$ of these tissues, respectively. ${ }^{7}$ Second, Heinen et al detected MSI in at least one locus among the six loci examined in $17 \%$ of non-neoplastic mucosa, in $5 \%$ of dysplasias, and in $17 \%$ of carcinomas, and in two or more loci in $4 \%, 0 \%$, and $0 \%$ of these tissues, respectively. ${ }^{8}$ In our study, in the UC-LD with neoplasm group, MSI in at least one locus among six loci
$(M S I \geqslant 1)$ was seen in $56 \%$ of non-neoplastic mucosa, in $38 \%$ of dysplasias (LGD and HGD), and in $50 \%$ of carcinomas. In addition, MSI $\geqslant 2$ was seen in $9 \%, 8 \%$, and $50 \%$ of these tissues, respectively (tables 3 and 6 )

The first question was why was MSI detected so frequently in non-neoplastic mucosa in UC, and whether such an alteration was transient or not. Brentnall et al suggested that MSI within non-neoplastic mucosa reflects the saturation of the DNA repair mechanisms as a result of chronic inflammation. They also examined MSI in acute inflammation of ischaemic and infectious colitis, but detected no alteration. ${ }^{7}$ Chronic inflammation may produce enough DNA damage to exceed the capacity of the DNA repair mechanisms. ${ }^{7}$ There is support for this hypothesis from a study performed in Escherichia coli. ${ }^{19}$ Moreover, there have been some reports regarding modifications in the capacity of DNA repair mechanisms. Brentnall et al suggested that an intronic splice site substitution in MSH2 may predispose to cancer in the setting of $\mathrm{UC}^{20}$ Cravo et 
Table 5 Microsatellite instability (MSI) in non-neoplastic epithelium

\begin{tabular}{llccl}
\hline Group & Matts's score & No. of samples & MSI $\geqslant 1$ locus & MSI $\geqslant 2$ loci \\
\hline UC-LD with neoplasm & 1 or 2 & 19 & $11(58 \%)$ & $1(5 \%)$ \\
& 3 or 4 & 4 & $2(50 \%)$ & $1(25 \%)$ \\
& Total & 23 & $13(57 \%)$ & $2(9 \%)$ \\
\multirow{5}{*}{ UC-LD without neoplasm } & 1 or 2 & 5 & $1(20 \%)$ & 0 \\
& 3 or 4 & 9 & $9(100 \%)$ & $6(67 \%)$ \\
& Total & 14 & $10(71 \%)$ & $6(49 \%)$ \\
UC-SD & 1 or 2 & 3 & $1(33 \%)$ & 0 \\
& 3 or 4 & 9 & $7(78 \%)$ & $1(11 \%)$ \\
& Total & 12 & $8(67 \%)$ & $1(8 \%)$ \\
\hline
\end{tabular}

UC-LD, ulcerative colitis of long duration; UC-SD, ulcerative colitis of short duration.

Table 6 Microsatellite instability (MSI), p53

overexpression, and proliferative activity in ulcerative colitis of long duration with neoplasm samples

\begin{tabular}{lllll}
\hline Class & $\begin{array}{l}\text { No. of } \\
\text { samples } \\
\text { examined }\end{array}$ & $\begin{array}{l}\text { MSI } \\
\text { locus }\end{array}$ & $\begin{array}{l}\text { MSI } \geqslant 2 \\
\text { loci }\end{array}$ & $\begin{array}{l}\text { p53(+) } \\
\text { or (++) }\end{array}$ \\
\hline NFD & 23 & $13(56 \%)$ & $2(9 \%)$ & 0 \\
IFD-N & 2 & $1(50 \%)$ & 0 & 0 \\
IFD-P & 7 & $1(14 \%)$ & 0 & $2(29 \%)$ \\
LGD & 6 & $4(67 \%)$ & $1(17 \%)$ & $4(67 \%)$ \\
HGD & 7 & $1(14 \%)$ & 0 & $4(57 \%)$ \\
Ca & 4 & $2(50 \%)$ & $2(50 \%)$ & $3(75 \%)$ \\
\hline
\end{tabular}

$\mathrm{Ca}$, carcinoma; HGD, high grade dysplasia; IFD-N, indefinite for dysplasia, probably negative; IFD-P, indefinite for dysplasia, probably positive; LGD, low grade dysplasia; NFD, negative for dysplasia.

al suggested that a low folate status is an additional cause for patients with UC having MSI in the non-neoplastic mucosa. ${ }^{21}$

In previous studies, the grade of inflammation was not discussed in relation to MSI. However, in our study, in the UC-LD without neoplasm group, MSI was detected significantly more frequently in severe inflammatory lesions than in mild inflammatory lesions. In addition, in non-neoplastic mucosa of UC-LD with neoplasm, the frequency of $M S I \geqslant 2$ was less than in UC-LD without neoplasm, in spite of the long duration and past history of active inflammation suggested by atrophic regenerative mucosa. We thought that MSI could not be demonstrated without clonal expansion. But in UC with severe inflammation, clones with MSI might disappear because of the inflammation and ulceration. Therefore, we suggested that MSI in inflammation reflected the severity of chronic inflammation at the point of examination and did not necessarily imply a deficiency in the DNA repair process. It could not be excluded that the correlation between the degree of inflammation and the occurrence of MSI is an effect of inflammatory cells, although we tried to sample only the epithelium and took no lymphoid follicles from the mucosa. Our samples from inflamed epithelium might include some inflammatory cells, although the effect of the scattered inflammatory cells should be small because clonal expansion would not occur there.

The second question was whether MSI could cause carcinogenesis in UC. A proportion of genetic alterations might repeatedly escape repair and some of them could hit target genes, which was not clarified in our study. With regard to non-neoplastic lesions, $M S I \geqslant 2$ was found significantly more often in UC-LD without neoplasm than in UC-SD when comparing mucosa with a similar grade of inflammation. We suggest that the chronic inflammatory process causes accumulation of MSI. In this condition, a deficiency in the DNA mismatch repair genes might not be necessary. In our study, MSI in neoplastic epithelium was less frequent, and MSI in BAT 26, which is almost $100 \%$ sensitive for colorectal cancer with replication error phenotype, ${ }^{22}$ was rare even in the lesions with $M S I \geqslant 2$. Moreover, MSI in this situation only represents a tendency to genetic instability, and not a specific mutation in the target genes. In our study, we could not detect MSI in TGF- $\beta$ RII (poly A repeat), which is a major target gene of a genetic instability carcinogenic pathway. ${ }^{13}$ In a previous study, Souza et al detected a TGF- $\beta$ RII alteration in $17 \%$ of UC associated neoplasms with MSI, and in $81 \%$ of unstable colorectal cancers. ${ }^{23}$

With regard to neoplastic lesions, although $18 \%$ expressed $\mathrm{MSI} \geqslant 2$, p53 overexpression was shown in $65 \%$. Moreover, MSI and p53 overexpression were not associated; they seemed to occur independently. The overexpression of $\mathrm{p} 53$ has been detected in UC associated neoplasms. Taylor et al did not detect overexpression in the non-neoplastic mucosa samples they studied, although it was found in $30 \%$ of dysplasia cases, and $52 \%$ of cancer cases - a similar frequency to that in sporadic colorectal carcinomas (48\%). They suggested that alteration of the p53 locus might be important in the progression from the nonmalignant phenotype to carcinoma. ${ }^{24}$ Ajioka et al detected overexpression in $75 \%$ of dysplasias and $85.7 \%$ of carcinomas. ${ }^{25}$ Therefore, we suspected that the tumour suppressor pathway represented by p53 overexpression might be involved in the carcinogenesis associated with UC. In addition, UC associated neoplasm is similar to sporadic colorectal cancer, and different from HNPCC, which is invariably associated with the MSI pathway. However, it is possible that $M S I \geqslant 2$ detected in two of the four invasive cancers resulted from a deficiency of DNA mismatch repair genes.

In summary, MSI in active inflammatory lesions may be a transient event, and may not be involved in carcinogenesis in UC. Therefore, the influence of inflammation should be taken into account when estimating MSI in chronic inflammation cases. In past studies on MSI in UC, the extent of inflammation has not been estimated. In addition, MSI is a phenotypically silent event, as long as a mutation in a target gene does not emerge and cause carcinogenesis.

1 Jefferys AJ, Wilson V, Neumann R, et al. Amplification of human minisatellites by the polymerase chain reaction: towards DNA fingerprinting of single cells. Nucleic Acids Res 1998;16:10953-71

2 Weber JL, May PE. Abundant class of human DNA polymorphisms which can be typed using the polymerase chain reaction. Am f Hum Genet 1989;44:388-96.

3 Aaltonen LA, Peltomaki P, Leach FS, et al. Clues to the pathogenesis of familial colorectal cancer. Science 1993; 260:812-16.

4 Thibodeau SN, Bren G, Schaid D. Microsatellite instability in cancer of the proximal colon. Science 1993;260: 816-19. 
5 Ionov Y, Peinado MA, Malkhosyan S, et al. Ubiquitous somatic mutations in simple repeated sequences reveal a ism for colonic carcinogenesis. Nature 1993;

6 Suzuki H, Harpaz N, Tarmin L, et al. Microsatellite instability in ulcerative colitis-associated colorectal dysplasia and cancer. Cancer Res 1994;54:4841-4.

7 Brentnall TA, Crispin DA, Bronner MP, et al. Microsatellite instability in non-neoplastic mucosa from patients with chronic ulcerative colitis. Cancer Res 1996;56:1237-40.

8 Heinen CD, Noffsinger AE, Belli J, et al. Regenerative lesions in ulcerative colitis are characterized by microsatellite mutation. Genes Chromosomes Cancer 1997;19:170-5.

9 Devrocede GJ, Taylor WF, Sauer WG, et al. Cancer risk and life expectancy of children with ulcerative colitis. $N$ Engl $\mathcal{f}$

10 Riddell RH. The precancerous phase of ulcerative colitis. Curr Top Pathol 1976;63:179-219.

11 Riddell RH, Goldmann H, Ransohoff DF, et al. Dysplasia in inflammatory bowel disease: standardized classification with provisional clinical applications. Hum Pathol 1983;14 931-68.

12 Matts SGF. The value of rectal biopsy in the diagnosis of ulcerative colitis. $Q \mathcal{F}$ Med 1961;120:393-407.

13 Parsons R, Myeroff LL, Liu B, et al. Microsatellite instabilParsons R, Myeroff LL, Liu B, et al. Microsatellite instabilII receptor gene in colorectal cancer. Cancer Res 1995;55 $5548-50$.

14 Brentnall TA, Chen R, Lee JG, et al. Microsatellite instability and K-ras mutations associated with pancreatic adenocarcinoma and pancreatitis. Cancer Res 1995;55:4264-7.

15 Semba S, Yokozaki H, Yamamoto S, et al. Microsatellite instability in precancerous lesions and adenocarcinomas of stomach. Cancer 1996;77:1620-7.
16 Hamamoto T, Yokozaki H, Semba S, et al. Altered microsatellites in incomplete-type intestinal metaplasia adjacent to ellites in incomplete-type intestinal metaplasia adjacen

17 Peng H, Chen G, Du M, et al. Replication error phenotype and p53 gene mutation in lymphomas of mucosaand p53 gene mutation in lymphomas of mucosa-

18 Meltzer SJ, Yin J, Manin B, et al. Microsatellite instability occurs frequently and in both diploid and aneuploid cell populations of Barrett's-associated esophageal adenocarcinoma. Cancer Res 1994;54:3379-82.

19 Schaaper RM, Radman M. The extreme mutator effect of Escherichia coli mutD5 results from saturation of mismatch repair by excessive DNA replication errors. EMBO f 1989;8:3511-16.

20 Brentnall TA, Rubin CE, Crispan DA, et al. A germline substitution in the human MSH2 gene is associated with highcrate dysplasia and cancer in ulcerative colitis. Gastroentergrade dysplasia and cancer in ulcerative colitis. Gastroenter-
ology 1995;109:151-5.

rque CM, Souza LS, et al. Microsatellite instability in non-neoplastic mucosa of patients with ulcerative colitis: effect of folate supplementation. $A m$ f Gastroenterol 1998;93:2060-4

22 Hoang JM, Cottu PH, Thuille B, et al. BAT-26, an indicator of the replication error phenotype in colorectal cancers and cell lines. Cancer Res 1997;57:300-3.

23 Souza RF, Lei J, Yin J, et al. A transforming growth factor $\beta 1$ receptor type II mutation in ulcerative colitis-associated neoplasms. Gastroenterology 1997;112:40-5.

24 Taylor HW, Boyle M, Smith SC, et al. Expression of p53 in colorectal cancer and dysplasia complicating ulcerative colitis. Br f Surg 1993; 80:442-4.

25 Ajioka Y, Watanabe H, Matuda K. Over-expression of p53 protein in neoplastic changes in ulcerative colitis: immunohistochemical study. I Gastroenterol 1995;30(suppl VIII): 33-5.

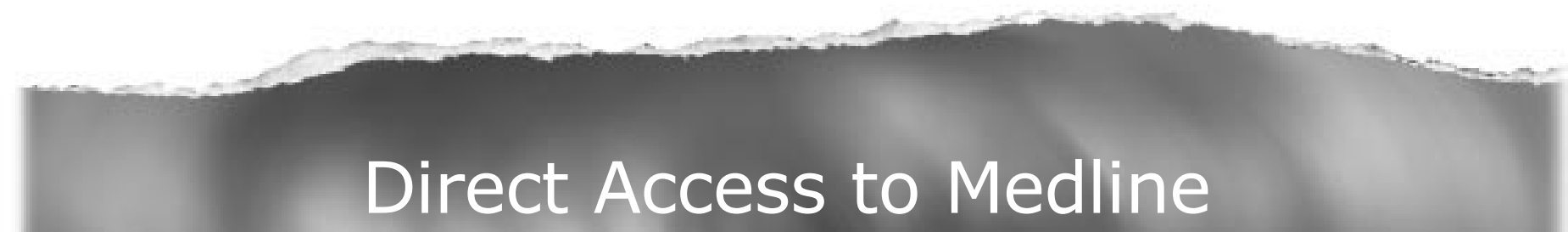

Medline

Link to Medline from the homepage and get straight into the National Library of Medicine's premier bibliographic database. Medline allows you to search across 9 million records of bibliographic citations and author abstracts from approximately 3,900 current biomedical journals.

\section{www.jclinpath.com}

